\title{
The Implications of Adopting and Implementing Electronic Human Resource Management Practices on Job Performance
}

\author{
Talatu Raiya Umar ${ }^{1, *}$, Bilkisu Abdulkadir Yammama ${ }^{2}$, Rashidat Otse Shaibu ${ }^{2}$ \\ ${ }^{1}$ Department of Management Studies, College of Business and Management Studies, Kaduna Polytechnic, Nigeria \\ ${ }^{2}$ Department of Social Sciences, College of Administrative Studies and Social Sciences, Kaduna Polytechnic, Nigeria
}

Email address:

raiyau@yahoo.com (T. R. Umar)

${ }^{*}$ Corresponding author

To cite this article:

Talatu Raiya Umar, Bilkisu Abdulkadir Yammama, Rashidat Otse Shaibu. The Implications of Adopting and Implementing Electronic Human Resource Management Practices on Job Performance. Journal of Human Resource Management. Vol. 8, No. 2, 2020, pp. 96-108. doi: $10.11648 /$ j.jhrm.201200802.17

Received: March 8, 2020; Accepted: March 24, 2020; Published: April 23, 2020

\begin{abstract}
Past literature supports positive links between electronic human resource management practices (E-HRM), and job performance. However, poor application of e-HRM practices in the Nigerian public sector resulted in poor job performance and unwholesome ethical practices. As a result, calls for further research have been suggested, particularly on the direct process through which the adoption and implementation of e-HRM practices such e-communication; e-compensation, e-training and e-performance appraisal are likely to influence job performance. Hence, the purpose of this research is to investigate the relationship between electronic Human resource Management (E-HRM) practices and job performance (i.e. task, contextual, adaptive performance, and counterproductive work behaviour at the individual level. We employed a quantitative approach with survey from 214 academic and non academic staff in five higher institutions in Northern part of Nigeria. Using partial least square structural equation modelling (PLS-SEM), the quantitative results indicated that some of the components of E-HRM practices were positively associated with job performance. For instance, both e-communication, and e-compensation were significantly and positively related to all the dimensions of job performance (i.e. task, contextual, adaptive, and counterproductive work behaviour. Also, e-training was found to be positively related to task and adaptive performance only. Similarly, results showed that e-performance appraisal practice was only related to contextual performance and counterproductive work behaviour. On the contrary, e-training practice demonstrated no significant effect on contextual performance and counterproductive work behaviour. Similarly, no significant direct effect was found between e-performance appraisal and task and adaptive performance. Implications of the findings for future research and practice, as well as the limitations of the study are highlighted.
\end{abstract}

Keywords: Job Performance, E-Hrm, E-Training, E-communication, E-compensation, E-performance Appraisal

\section{Introduction}

Undoubtedly, as at today, organisations are faced with fierce global competition, and are thus, compelled to keep pace with developments by having adaptive and innovative insights and in order to remain relevant, organizations hugely need the contributions of highly performing individuals (employees), so as to deliver the products and services they specialized in $[1,2]$. Moreover, its success hugely depends on the participation and the job performance of its employees.
Importantly, past literature on the determinants of job performance have largely focused on organizational, personal, and job related factors such as recruitment and selection (e.g. [3], development [4-6], integration [7] workplace social inclusion [8], job insecurity [9], emotional intelligence [10], job passion [1] organizational commitment $[11,12]$ psychological well-being [13], and job satisfaction [14]. In general, these studies have found that organizational, personal and job related factors are likely to have a significant effect on job performance. But, most of these 
studies did not attempt to operationalise employee job performance as a multi-dimensional construct as suggested by earlier researchers [15-17]. And recent researchers rather majority of these studies operationalized job performance as a unidimensional construct [18, 4]. Arguably, it is an indication that studies that operationalized employee job performance as unidimensional construct had not comprehensively captured the actual measurement of job performance. In addition, in spite of the advancement made investigating each of these theoretical perspectives to describe job performance, there has been little, if any, role for technology in explaining job performance at the individual level. Taken together, it is clear that management research has not focused much attention on the role technology (i.e. e-HRM) plays in influencing employee job performance [19, 20].

Even though e-HRM has been identified as a relatively new concept in management literature, it is continuously gaining popularity and attracting attention from both the business and academic world, in fact most of the extant literature supports the assertion that e-HRM practices offer organisations with a variety of potential benefits [21, 22, 23, 24]. For example, it has been revealed that e-HRM enhances HR efficiency, decreases administrative burdens, saves time, facilitates HR planning, reduces costs, as well as improves job performance among employees [25, 26, 27]. But, yet, it has been argued that as a matter of strategic urgency, organisations should develop a policy framework for the use of E-HRM practices, in order to assist in the creation of a highly competent, effective and performing workforce in the organisation [28].

But, more specifically the performance of employees in the developing nation like Nigeria is characterized by inefficiency [29], lackadaisical attitude to the job [30], among others. This perhaps is very evident in the way organisations in Nigeria are battling with ineffective filing system and where manually documented records become very irretrievable and even loss in some instances. These problems remain incessant and that made the Nigerian Government to establish numerous public service reform measures such as SERVICOM, which is an agency that is targeted at enhancing the performance of employees at the workplace for optimum service delivery and improved organisational efficiency and effectiveness.

To date, it is widely acknowledged that there is paucity of research on e-HRM and job performance in Nigeria more specifically in public tertiary organisations. To address this, the need for a comprehensive study that will capture the relationship between electronic human resource management practices and all the four elements of job performance as a multi-dimensional construct becomes necessary [31]. In this respect, each of these four aspects of job performance (task, contextual and adaptive performance, and counterproductive work behaviour) could likely offer unique contribution toward improving organizational effectiveness [4]. More importantly, as recently posited that designing, adopting, and implementing (e-HRM) practices is highly needed to facilitate the development of an effective, competent and highly performing workforce in the public sector $[32,33]$.

Therefore, the current study seeks to address this knowledge gap by investigating whether e-HRM practices hold a key to explain job performance at the individual level. Towards this end, this paper is structured as follows. In the first part, we reviewed the relevant literature related to E-HRM practices, and job performance leading towards theoretical development. We then explained the methodology used for the present research in the third part. In the fourth part, we present the findings and discuss them in the light existing empirical studies. In the fifth part, conclusions are drawn. We then highlight the managerial implications of the results in the sixth part. In the final part, the limitations and recommendations for future research have been highlighted.

\section{Review of Literature}

\subsection{Job Performance}

Job performance has typically been conceptualized as the "actions and behaviours that are under the control of the individual that contribute to the goals of the organization" [34]. These behaviors can be differentiated based on their effectiveness, which has a potential influence on outcomes [15]. A person's job performance is the most important research criterion of organizational behavior, and is simply defined as "all kinds of behaviors at work" [35]. It comprises grades, results, values, and achievements obtained by an employee from work. In a narrow sense, job performance is described as employee productivity, while in a broader sense it is described as the combination of efforts, skills, and results attained and is critical for both employees and organisation [36]. Put differently, it simply describes behaviors of employees that can make a significant difference to the accomplishment of the organizational goal [37]. This signified that individual employee performance is the expected value of what workers do in organizations which are significant towards increasing organizational effectiveness.

Job performance at the individual level, as conceptualized refers to "those actions or behaviors under the control of the individual, that contribute to the organization's goals and that can be measured according to the individual's level of proficiency," which includes both productive and counterproductive employee behaviours that contribute to or detract from organizational goals [38]. Previous studies have generally considered employee job performance as a two dimensional construct. For instance, it has been contended that the entire job performance at the individual level domain could be encompassed by the comprehensive dimensions of contextual performance and task performance or three dimensional construct, namely, task performance, organizational citizenship behavior, and counterproductive work behavior [15, 39, 34]. But, according to job performance at the individual level is a multidimensional construct that is composed of four dimensions: task Performance, contextual performance, adaptive performance, and counterproductive work behaviour [40]. Other Studies have recognized four broad classes of employee behaviors, namely, task performance, contextual performance, adaptive performance 
and counterproductive work behaviour performance [15, 34]

Several studies have opined that task performance is the most important feature of work behaviors, which in many cases have been considered as a synonym for the term "overall job performance" More so, it has been described 'as the effectiveness with which employee (job incumbents) perform activities or behaviors that contribute towards achieving the organization's technical core (objectives) either directly by carrying out a part of its technological process, or through indirect ways by providing the needed services or materials" $[15,36]$ Contextual performance as a second dimension refers to an employee's personal effort that is not directly linked to his/her main tasks but are important in that it shapes the organizational, social, and psychological background and can facilitate task activities and processes [40]. On same vein, contextual performance is defined "as individual behaviors that support the organizational, social, and psychological environment in which the technical core must function" Contextual performance involves behavior of an employee that is not within the established job description but still encourages organizational effectiveness. More so, argued that contextual performance contributes to organizational efficiency by serving as organizational, social, and psychological viewpoints in which the practical and technical core functions operate [15].

The third dimension, adaptive performance is defined as the degree to which an individual adapts to changes in a work roles or work system, examples include, dealing with uncertain or unpredictable, solving problems creatively, learning new tasks, technologies, work situations, and adapting to other individuals, cultures, or physical surroundings [34]. The final dimension, counterproductive work behavior, is defined as behavior that harms the well-being of the organization such as absenteeism, theft, off-task behavior, misuse of time and resources, misuse of information, poor-quality work, and poor attendance [4]

For this research, four dimensions of employee job performance that increase organizational effectiveness based on prior study are considered [4]. They include: task performance, contextual performance, adaptive performance, and counterproductive work behaviour $[15,31]$.

Nonetheless, we are not suggesting that other constructs as domains of job performance (e.g., job-specific task proficiency, in-role performance are unimportant [41]. Rather, we maintain that task performance, contextual performance, adaptive performance, and counterproductive work behavior could collectively provide a broadly comprehensive (yet parsimonious) accounting of the construct space of overall individual job performance. However, we believe these four types of dimensions can be considered to capture the full range of behaviors that constitute individual job performance in virtually any job. The relevance of the four dimensions, and their exact indicators, might however differ on the basis of the specific context.

\subsection{Electronic Human Resource Management (E-HRM) Practices}

Although several researchers agree that performance is a process but, there is paucity of studies to disentangle the various aspects of the performance process and more importantly, most of the extant literature has remained confined to particularly person-specific predictors [42, 43]. As a result, situational predictors that are generally noted to be significant in disentangling the various aspects of the performance process have largely remained 'untested' in connection to the need to arrive at a more comprehensive understanding of what happens while individuals are performing. For example, E-HRM practices are notably acknowledged and empirically modeled for their significance in predicting key individual employee behaviours and outcomes [21, 22, 45, 23, 46, 27]. Surprisingly, only little scholarly attention can be traced upon the relationship between E-HRM practices and job performance hence making it very unclear with many questions still unanswered [27, 47].

Other studied have also identified the importance of e-HRM practices that helps integrate information and mechanisms between human resource department and IT departments. Particularly, given that HR practices notably exist in any other organization, highlighting how employees' job performance may be improved upon electronically through them would responsively allow employees and the management greater accessibility to human resource related services and information through the organisation's web portal or intranet [48, 49].

Arguably, a fundamental issue with research on job performance is that it has mainly focused on person-specific variables $\mathrm{s}$ and, therefore, the potential role of electronic Human Resource Management (e-HRM) practices in enhancing job performance at the individual level has rarely been explored [23, 2].

Accordingly it has becomes increasingly important to maintain, improve, and optimize the job performance of employees [50]. As such the success of an organization always depends on the participation and job performance of their employees. They are the one who are responsible in achieving the vision and goals of the organization. For example, prior studies have argued that high performing employees get promoted, awarded and honored. More so, career growth for employees who perform well on the job are much better than those of moderate or low performing individuals [51].

\subsubsection{Electronic Training Practice (E-training)}

Training is viewed as an activity targeted to enhance additional skills or competency in an employee on the job one currently possesses in order to increase the performance [52]. Meanwhile, e-training is described as the provision of E-learning facilities, modules as well as web-based training opportunities through the Internet [53]. Further, described e-training as "the use of technology to deliver specific knowledge to an employee through a medium as internet or intranet, using print (e-text, eBooks, e-magazines), audio (streaming audio, audio tape), video (video tape, streaming video, satellite transmission, cable), reviews and examinations (electronic, interactive, paper), and synchronous-chat (videoconferencing, and teleconferencing or communication 
(asynchronous, threaded discussions, weblogs, forums [54, 55].

The relevance, benefits and advantages of e-training have been extensively highlighted [56]. For instance, it is suggested that using e- training systems, may likely decrease delivery cycle time because organisations are able to deliver training to many people quickly, increase learner convenience all at lower costs. Interestingly, prior studies have also found that adopting E-HRM for training and development purposes could result in cost reduction by eliminating the time away from work, costs of travel, training material and refresher courses [57]. Specifically, the adoption of e-learning promotes a better and more effective learning process, as well as enhancing high performing workforce [58, 59]. On same note, the result of a previous study conducted offers clear evidence on the importance of e-training within European organisation's training strategies and projects a better picture of its application [57]. The findings of the study indicated that In the UK, Benelux, and Spain and, nearly $40 \%$ of organisations train more than $50 \%$ of their employees through e-training system. Therefore, appropriate e- training opportunities can offer and boost employee performance as well as the continuous development of human resources in order to keep organizations ahead of their competitors [60, 61].

Previous studies have acknowledged a significant relationship between e-training opportunities with employee outcomes [62, 63, 54]. More so, handful of studies can also be tracked outlining the significant relationship between etraining and job performance $[59,64]$. Other studies have also demonstrated the influence of e-training on job performance at the individual level [59, 63]. For example, existing literatures have revealed a positive and significant association between e-training and employees' job performance [59, 65, $66]$.

A study conducted found the effectiveness of distance and online learning [67]. It was established that about $92 \%$ of all distance and online education studies found that distance and online education is at least as effective, if not better, than traditional education. Similarly, an investigation established that e-training is positively and significantly related to job performance among employees of Ministry of Education in the Kingdom of Bahrain [59].

These findings led to assert that e-training assists in keeping employees' skills current to aid bottom-line performance, more particularly, they also revealed that employees who perceived e-training to be effective demonstrated improvement in their job performance than those who saw e-training as ineffective. This implies that the adoption and implementation of effective e-training systems is likely to produce a more committed, satisfied, productive and higher job performers.

Summarily, in the training literature, findings revealed that the primary intent of e-training is to improve job performance of employees and the degree of satisfaction felt by the employee, and to also produce a productive and performing workforce [65]. Despite the importance of continuous training and development in current times, unfortunately, there is a scarcity of research on e-training and job performance. Moreover, suggestions from the performance literature at the individual level also highlight it as an important research gap, requiring urgent empirical investigation. Therefore, based on the above highlighted arguments and empirical evidences the following hypotheses are proposed:

H1a: E-Training is positively related to task performance.

H1b: E-Training is positively related to contextual performance.

H1c: E-Training is positively related to adaptive performance.

H1d: E-Training is positively related to counterproductive work behavior.

\subsubsection{Electronic Communication Practice}

The use of e-communication in human resource management practices involve sending and receiving messages electronically through computer systems or the internet such as voicemail, email, cell phone and others [68]. E-communication systems facilitate the efficient and effective conduct of human resource functions. It offers workers access to the internet in a fast, effective and easy way and also assists employees to perform their jobs [69]. In addition, a prior work discovered some uses of E-HRM in communication, which include, web-based information sharing facilities, web-based on-line suggestion schemes to drive employees to greater levels of creative thinking and performance, team briefing via intra-mail systems, and an open-door management approach, which is enabled via various electronic communication channels with the workforce [70].

Being able to apply ICT for workplace related tasks, anytime and anywhere, can possibly have benefits in terms of flexibility, efficiency, and performance [71]. For instance, when employees experience appropriate communication in their organization like receiving timely and adequate feedback information electronically, then favorable organizational outcomes from such workers would be expected. Undeniably, organizations continue to inject huge investments to develop virtual information and communication technology (ICT) platforms to facilitate effective communication and, consequently, improve employees' job performance [72].

Moreover, an empirical study indicated that e-communication practice significantly influences job performance among a sample of early-career professionals employed in a range of different types of organizations in Mid-Atlantic United States [73]. This was in tandem with the findings of a similar study which also revealed that e-communication led to higher levels of employee performance among ICT professional in the USA [74]. In addition, another research also established positive relationship between e-communication and employee performance [75]. Based on the above highlighted arguments and empirical evidences the following hypotheses are proposed:

H2a: E-Communication is positively related to task 


\section{performance.}

H2b: E-Communication is positively related to contextual performance.

H2c: E-Communication is positively related to adaptive performance.

H2d: E-Communication is positively related to counter-productive work behavior.

\subsubsection{E-Compensation Practice}

In the recent years, compensation and reward systems have become the critically competitive factor for attracting, motivating, and retaining the crucial work force in an organization. Accordingly E-compensation refers to using ICT in designing the compensation and benefit packages for the workforce that assists in ensuring that the salaries are fairly distributed, in tracking the records of an employee benefit package and crucial compensation information [76]. It also aids the managers to develop the organisation's budget, analyzing the effect of current incentive systems and ensuring the fairness of their compensation system, as well as accessibility to compensation information and data through the organisation's intranet or over the internet in which all the employees would be able to access it via browsers in which an individual employee can make his or her own decisions by electronically selecting his/her preferred benefits and rewards [76, 25]. In addition, it streamlines the cumbersome bureaucratic tasks through the introduction of workflow functionality and real-time information processing in a cost effective manner. Consequent upon that, an increasing number of organisations are turning to technology to facilitate their job tasks and have started enhancing their compensation systems via the use of intranet and internet.

E-Compensation is also considered to be one of the key determinants that could influence the job performance of employee [77, 78]. Empirical studies on the relationship between e-compensation and job performance revealed that e-compensation positively relates with job performance [79, 80]. More importantly, a study found that employees mostly seek to remain in an organization that can effectively manage the compensation and rewards systems for employees [77]. This implied that employees prefer to remain and work in organizations that can allow them to make their own decisions by electronically selecting their preferred benefits and rewards and in return perform optimally in terms of task, contextual, adaptive, and counterproductive work behaviours.

Based on the above arguments, the following hypotheses are, thus, formulated:

H3a: E-Compensation is positively related to task performance.

H3b: E-Compensation is positively related to contextual performance.

H3c: E-Compensation is positively related to adaptive performance.

H3d: E-Compensation is positively related to counterproductive work behavior.

\subsubsection{Electronic-Performance Appraisal Practice}

Electronic performance appraisal (e-performance appraisal) refers to the use of technology necessary to produce systems and processes by which an employee is assessed and rated, according his/her performance on the tasks needed within the organisation [81]. E-performance appraisal systems, especially online systems offer numerous benefits for organisations such as centralizing HRM functions and allow easy access to wide variety of data and information about employees. Of particular relevance to organisations, when properly adopted, such systems have the potentials to improve employee performance and organisation's competitiveness [82]. More so, e-performance appraisal practice allows users to submit their ratings easily through the organisations network [83].

Conventionally, e-performance appraisal systems is used as an archive, which stores past assessments and permits comparisons between assessments to be done over time. Notably, it allows organisations to access and retrieve data from the employee's job description, and transfer the information into the evaluation from any computer that has internet and at any time making it easier and faster for the organisation to generate accurate HR related reports [84]. Mean while the opinion that an employee can also use the e-performance appraisal system to manage his or her own personal performance goals based on his/her performance appraisal results [85]. It is clear from the foregoing that e-performance appraisal system is likely helpful for collecting performance data and monitoring an employee's performance.

Arguably it is important to note that e-performance appraisal systems assists the organization retain and motivate top talent by gaining insight into top performers across the organisation, but, very limited research has been done to evaluate the impact of e-performance appraisal on employee behaviour and outcomes [86]. E-performance appraisals are seen as important in shaping employee behaviours, but they are more assumed than practically investigated. There is no doubt in the fact that e-performance appraisal is regarded as an important HRM practice, influencing employee behaviours including monitoring and enhancing employee performance [87].

Since e-performance appraisal has the potential to capture and store variety of information and data about employees it can be a valuable decision making tool $[88,89]$. For example, employees' database generated by such systems can be applied to identify low and high performers. Interestingly, e-performance appraisal practice enhances employee performance as it can continuously monitor performance, record a great deal of data, and measure this data unobtrusively [90]. It has been asserted that employee performance increases when employees perceive that electronic performance monitoring leads to more objective performance appraisals and improved performance feedback [91]. Similarly, employees appraised through electronic system that collects and reports wide range of performance criteria were found to accept their performance ratings as more accurate and fair [92]. Undoubtedly, findings from a prior study supported positive influence of e-performance appraisal on job performance of [82]. On same vein a positive 
link between e-performance appraisal and job performance was established in the context health professional workers in Greece [93]. Thus, the aforementioned evidence clearly suggests that:

H4a: E-Performance appraisal is positively related to task performance.

H4b: E-Performance appraisal is positively related to contextual performance.

H4c: E-Performance appraisal is positively related to adaptive performance.

H4d: E-Performance appraisal is positively related to counterproductive work behavior.

\section{Research Framework}

Based on the hypothetical statements and for a better understanding of the proposed relationships, the research model is developed as shown in Figure 1.

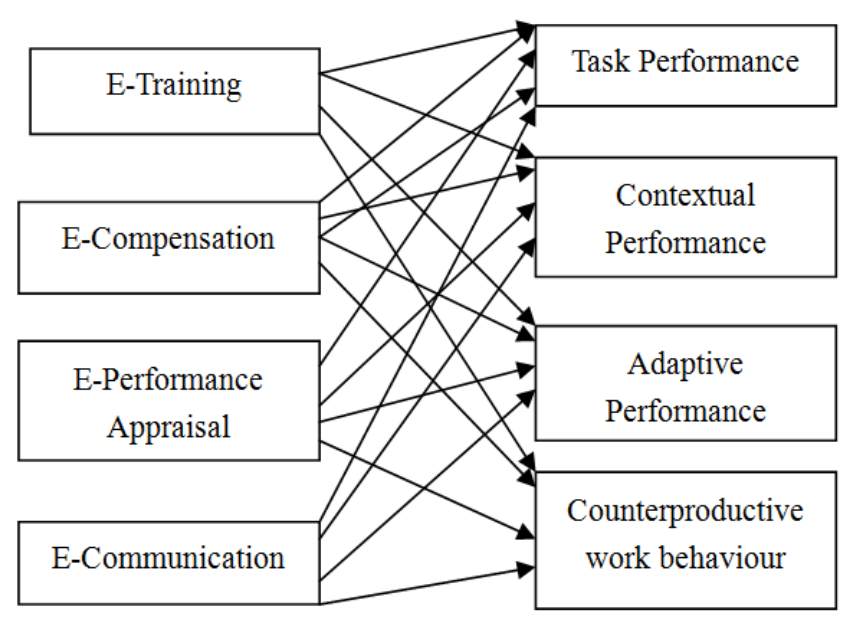

Figure 1. Research Framework

\section{Methodology}

\subsection{Participants}

Data were collected from 253 academic and non-academic staff of the six tertiary institutions in Northern part of Nigeria. In all, 214 questionnaires were returned, and among these returned questionnaires, 39 were discovered incomplete and hence were discarded. The remaining 214 were subjected to further analysis and interpretation. Most of the participant 184 (93.6\%) were male, while the remaining 30 (6.4\%) were female. On the basis of age grade, majority of the participants out of 214 are below $31-40$ years of age group (61.6\%), followed by below 30 years $(32.6 \%)$, and the remaining (7.8\%), to higher age groups. With regards to job experience, more than half $(55.4 \%)$ stated to have 11 years and above followed by 33.2 per cent having $6-10$ years of experience and the remaining 11.4 per cent had $0-5$ years of service work experience. The academic qualification of participants indicates that majority of the participants $(61.2 \%)$ had a master's qualification, whereas 29.4 per cent reported having a Degree/HND. The remaining 9.4 percent respondents are
PhD graduates.

\subsection{Measures and Instrumentation}

\subsubsection{Job Performance}

Individual work performance scale that contains task performance, contextual performance adaptive performance, and counterproductive work behaviour was used [4].

Task performance is operationalized as the behavior of an employee in relation to the quality, quantity and efficiency of the core activities he/she is assigned to perform. It was measured by 13 items. Contextual performance is operationalized as the behavior of an individual worker that is outside job description but increases the organizational effectiveness. We measured contextual performance with 16 items. To measure adaptive performance, 8 items developed was adopted [4]. Adaptive performance is operationalized as the extent to which employees behaviors adapt to the different changes in the work place. Finally, counterwork productive behaviour is operationalised as behavior that harms the well-being of the organization. It was measured by 10 -items.

\subsubsection{Electronic-HRM Practices}

Electronic-HRM practices were measured by three independent practices including e -compensation, ecommunication and e-performance appraisal. e -communication was measured by six-item scale adopted for this study from [94]. The scale has been developed to measure e-compensation. We also used an 11-item scale developed to measure e-performance appraisal [94].

\section{Data Analysis}

The present research ensured assumptions with respect to normality, linerarity and multicollinearity of the data prior to the conduct of the main analysis $[95,96]$. Consequent upon the attainment of these assumptions, partial least squares (PLS) path modelling approach was employed in conjunction with Smart PLS 2.0 software, as instrument of quantitative analysis [98]. The present study considers the application of PLS path modeling as the most suitable technique for the following reasons: Despite PLS path modeling sharing similarities with conventional regression approach, the PLS path modeling has the advantage of estimating many relationships simultaneously $[98,99]$. For example, it is regarded as one of the most powerful statistical tools in testing the links between indicators and their corresponding latent constructs (measurement model) and the links between constructs (structural model) at the same time [100].

The present research work applied a two-step process to determine the research model and this process involves assessing both the measurement (outer) model and structural (inner) model [101, 102].

\subsection{Measurement Model Assessment}

A measurement model evaluates the links between indicators and latent constructs [103, 104]. Herein, individual item reliability, internal consistency and discriminant, and 
convergent validity are determined.

Individual item reliability was determined through evaluating outer loadings of each of construct's measure [105]. Hence, any models which measures outer loadings of 0.70 or above are considered more reliable. Further, composite reliability coefficient was evaluated to determine internal consistency reliability of the employed measures. For this, the rule of thumb suggested was considered which contends that composite reliability coefficient should be no less than 0.70 [106] Ascertaining convergent validity is contingent upon the recommendations of [107]. Thus, the convergent validity is better evaluated through AVE scores, whereby it is recommended that each of the latent construct should value 0.50 or above [107]. For the present research work Table 1 presents further details in this regard.

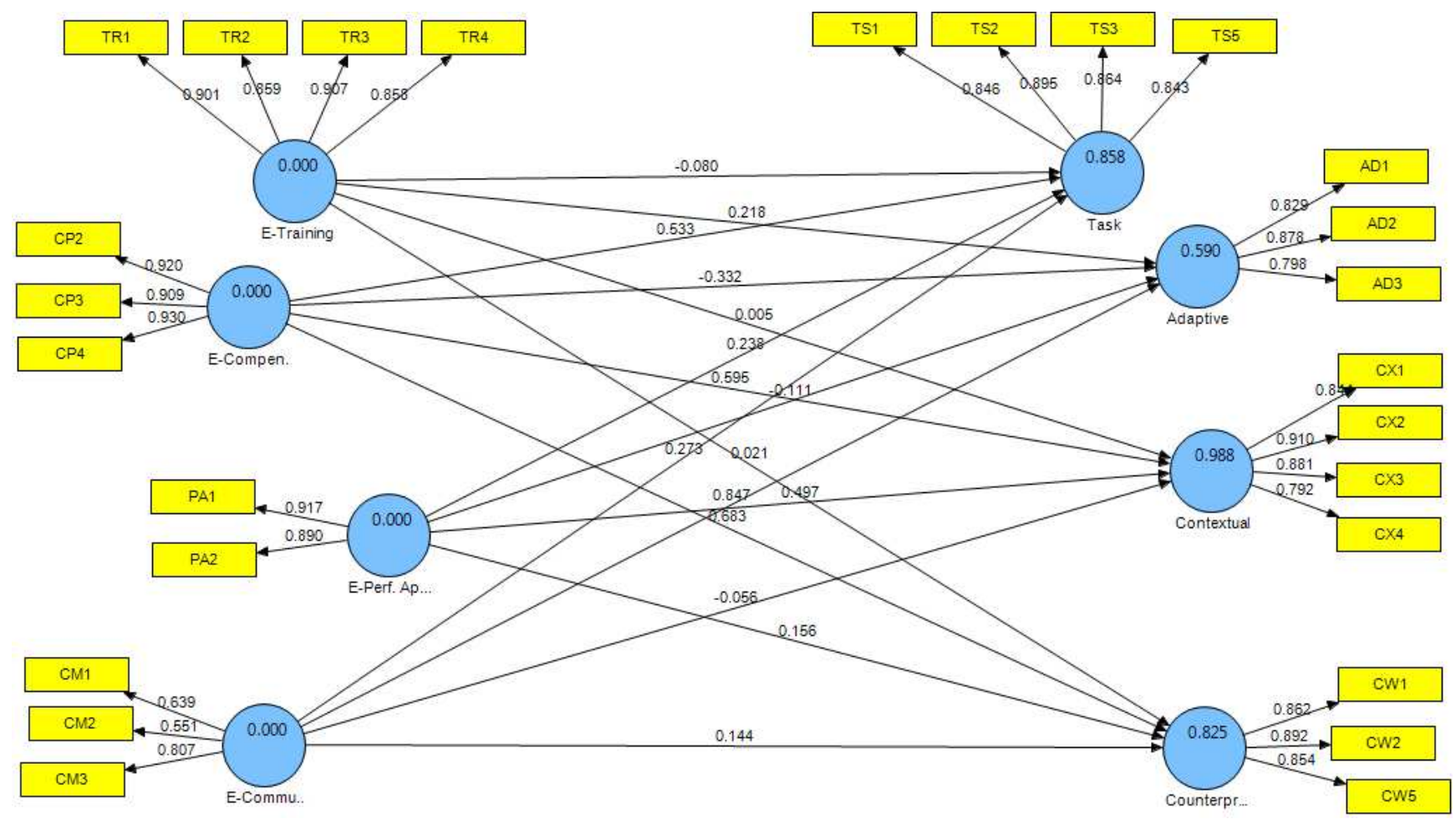

Figure 2. Measurement Model.

Table 1. Loadings, Composite Reliability $(C R)$ and Average Variance Extracted (AVE).

\begin{tabular}{lllll}
\hline Construct & items & Loadings & AVE & CR \\
\hline Job Performance & & & & \\
Task performance & TS1 & 0.846 & 0.746 & 0.959 \\
& TS2 & 0.896 & & \\
& TS3 & 0.864 & & \\
Contextual performance & TS6 & 0.843 & & \\
& CX1 & 0.841 & 0.662 & 0.906 \\
& CX2 & 0.910 & & \\
Adaptive performance & CX3 & 0.881 & & \\
& CX4 & 0.792 & & \\
Counterproductive work & 0.829 & 0.746 & 0.854 \\
behaviour & AD2 & 0.878 & & \\
& CW1 & 0.796 & & \\
E-Communication & CW2 & 0.862 & 0.673 & 0.891 \\
& CW6 & 0.854 & 0.686 & 0.897 \\
E-Compensation & CM2 & 0.839 & & \\
& CM3 & 0.861 & & \\
E-Performance & CP2 & 0.807 & & \\
appraisal & CP4 & 0.930 & 0.757 & 0.925 \\
\hline
\end{tabular}

\begin{tabular}{lllll}
\hline Construct & items & Loadings & AVE & CR \\
\hline \multirow{3}{*}{ E-Training } & PA2 & 0.890 & & \\
& TR1 & 0.901 & 0.741 & 0.875 \\
& TR2 & 0.869 & & \\
& TR3 & 0.907 & & \\
& TR4 & 0.858 & & \\
\hline
\end{tabular}

Table 1 showed that each of the construct's AVE has adequately attained the suggested threshold by ranging in between 0.556 and 0.733 . In addition, all of the constructs had a composite reliability above recommended threshold of 0.70 [102]. The reliability ranged from 0.787 to 0.878 . More so, discriminant validity was also determined following the suggestions that the square root of AVE should be higher than the compared reflective loadings of other constructs in a cross-loadings table [108]. Results of the study revealed that the AVE values of all the latent constructs have resulted in between 0.776 and 0.859 , thus, suggesting adequate discriminant validity has been achieved as per the recommendation of Fornell and Larcker.

\subsection{Structural Model Assessment}

At this level, PLS-SEM calculates the test of hypotheses and the significance of the path coefficients of latent constructs as contained in the research model. First, the significance of path 
coefficients of the main model was ascertained through applying bootstrapping procedures with 5,000 bootstrap samples on 214 cases to outline path coefficient's significance level of the direct theorized relationships [102]. The main direct effect model is depicted in table 2.

\subsection{The Main Effects}

This part presents the findings of the hypothesized main effects as predicted at the outset. Accordingly, the assessment criteria for affirming each hypothesis was the use of $t$-values greater than or equal to 2.326 at 0.01 and greater than or equal to 1.645 at 0.05 one-tailed level of significance for each path loading [107]. For example, bootstrapping results in Figure 2 and Table 2 showcase that e- training opportunities positively enhanced employees' job performance $(\beta=0.080, p=0.001)$, thus supporting our first theoretical hypothesis. Likewise, it could be recalled that we theorized that e-compensation is positively related to contextual performance. Results (Table 2 and Figure 2) outline that e-compensation had a significant impact in improving contextual performance $(\beta=0.595, \mathrm{p}=$ 0.001 ), thus this finding provide support for hypotheses $\mathrm{H} 3 \mathrm{~b}$ among others.

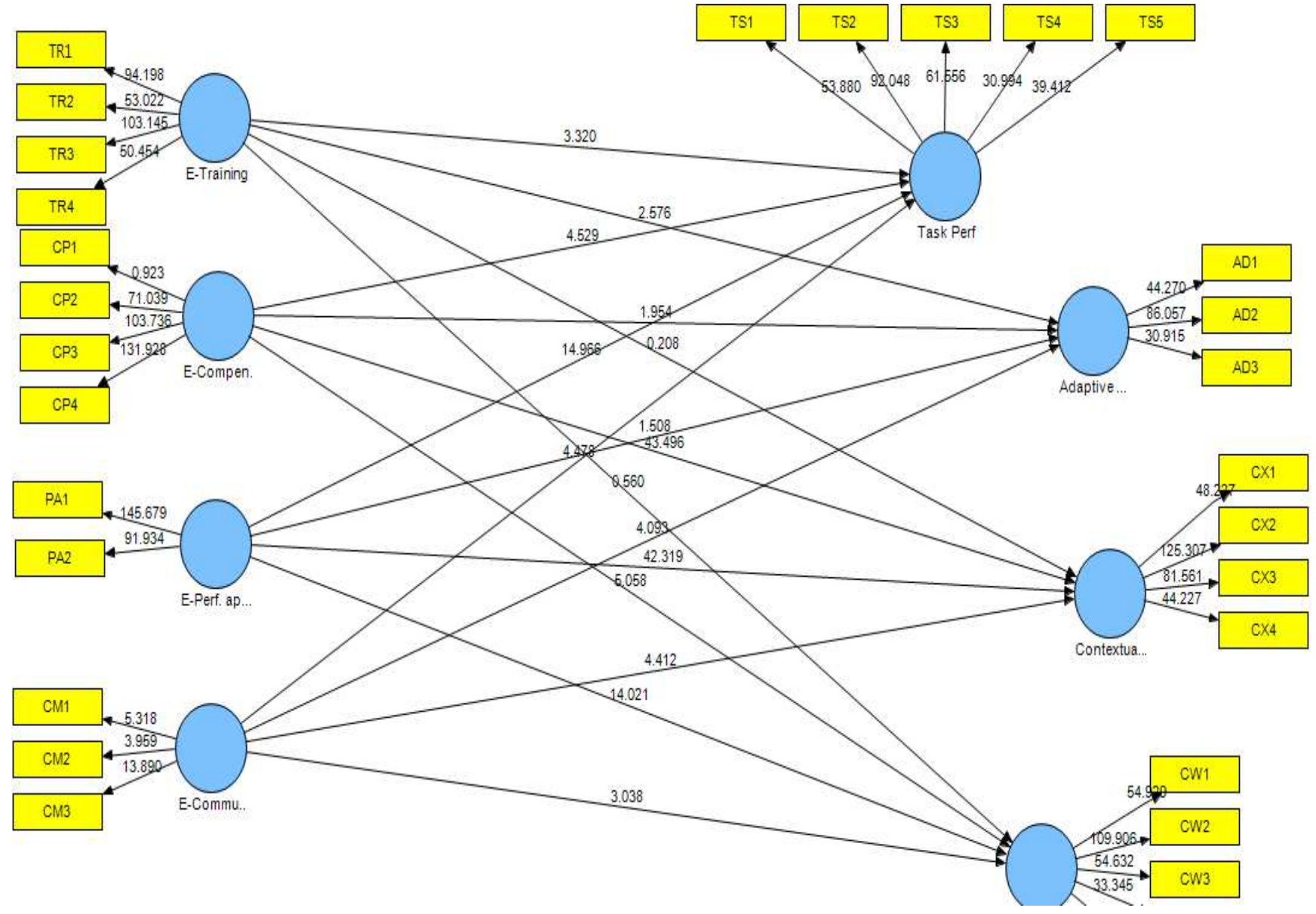

Figure 3. Structural model.

Table 2. Test of hypotheses.

\begin{tabular}{llll}
\hline H & Relationships & Beta & t-value \\
\hline H1a & e-training $\rightarrow$ Task performance & 0.080 & 3.320 \\
H1b & e-training $\rightarrow$ Contextual performance & 0.576 & 0.208 \\
H1c & e-training $\rightarrow$ Adaptive performance & 0.218 & 2.576 \\
H1d & e-training $\rightarrow$ counterproductive work behaviour & 0.021 & 0.560 \\
H2a & e-communication $\rightarrow$ Task performance & 0.273 & $4.478^{* * *}$ \\
H2b & e-communication $\rightarrow$ Contextual performance & 0.056 & $4.412^{* * *}$ \\
H2c & e-communication $\rightarrow$ Adaptive performance & 0.847 & $4.093 * * *$ \\
H2d & e-communication $\rightarrow$ counterproductive work behaviour & 0.144 & $3.038^{* * *}$ \\
H3a & e-compensation $\rightarrow$ Task performance & 0.533 & $4.529 * * *$ \\
H3b & e-compensation $\rightarrow$ Contextual performance & 0.595 & Not supported \\
H3c & e-compensation $\rightarrow$ Adaptive performance & 0.332 & Supported \\
H3d & e-compensation $\rightarrow$ Counterproductive work behaviour & 0.683 & Supported \\
H4a & e-performance appraisal $\rightarrow$ Task performance & Supported & Supported \\
H4b & e-performance appraisal $\rightarrow$ Contextual performance & Supported & $5.954^{* *}$ \\
\end{tabular}




\begin{tabular}{lllll}
\hline H & Relationships & Beta & t-value & Decision \\
\hline $\mathrm{H} 4 \mathrm{c}$ & e-performance appraisal $\rightarrow$ Adaptive performance & 0.111 & 1.508 & Not supported \\
$\mathrm{H} 4 \mathrm{~d}$ & e-performance appraisal $\rightarrow$ Counterproductive work behaviour & 0.156 & 1.402 & Not supported \\
\hline
\end{tabular}

Note $* * *$ indicated significance at $\mathrm{p}<0.01 ; * *$ indicated significance at $\mathrm{p}<0.05$.

\section{Discussion of Findings}

The present study aimed to investigate how certain e-HRM practices can influence task, contextual, adaptive performance, and counterproductive work behaviour of employees in the context of tertiary institution. Fundamentally, the research attempted to explore the direct relationship between e-l HRM practices, including-training e-communication, and e-compensation and e-performance appraisal with job performance.

Task performance is operationalized as the behaviors of an employee that are within his or her job description. Whiles adaptive performance refers to the extent to which workers adapt to the varying changes in their work place. In respect to task performance and adaptive performance the findings of the study revealed that all the four e- HRM practices with exception of e-performance appraisal had significant positive influence on task and adaptive performance. This clearly supported that the assertion that when employees perceived that their organization implemented ICT in designing the compensation and benefit packages, provided e-learning facilities, modules as well as web-based training opportunities through the Internet, and communication practices that involves sending and receiving messages electronically through computer systems, with these in place then the employees tend to demonstrate higher task and adaptive performance. These results supported the argument of past studies, as our findings show (E-HRM) and its components, has a significant positive correlation with job performance [76]. On the contrary, e-performance appraisal was not a predictor of task and adaptive performance. The possible reason for insignificant relationship is that not all activities in e-performance appraisal system influence employee performance positively. As a result, organisations need to create a comprehensive model for financial appraisal to evaluate employees fairly and consequently to motivate better employee performance.

Furthermore, contextual performance which is conceptualized as the activities of a worker that is not within his or her job description but still enhances organizational effectiveness.

In respect of contextual performance, the study supported that three e-HRM practices including e-communication, e-compensation and e-performance appraisal are good predictors of contextual performance. In contrast, the beta value of e-training is. $0.576(p=.208)$ which shows that one unit of change in the e-training makes 0.576 unit change in the job performance of the employees. Hence the result failed to accept the stated hypothesis that e-training has a significant positive impact on the job performance of the employees. Thus, suggesting that employee's perception on the presence of e-communication, e-compensation and e-performance appraisal systems provides them with adequate opportunities to exhibit more positive contextual behaviors. For this reason, it is suggested that for organization to achieve positive contextual performance, these e-HRM practices should be further be emphasized with more attention given. However, if they are left unattended, these practices, could results in less or even poor contextual performance.

Contrary to expectations, e- training and e-performance appraisal practices are not statistically significant with counterproductive work behaviour in this research work. This is an indication that presence of, e- training and e-performance appraisal practices may not necessarily influence more positive counterproductive work behaviour. It is suggested that Management could reduce employee counterproductive work behaviour by putting into action the adoption and implementation of employee oriented e-Hrm practices that may prevent the propensity to act against the organisations. In spite of the fact that, majority of e- HRM practices examined indicated positive relationships with different facets of job performance at the individual level, interestingly only e-communication and e-compensation practices demonstrated significant positive influence on all the four facets of job performance (task, contextual, adaptive, and counterproductive work behaviour.

From the foregoing, it is reflective that organisations should pay more attention particularly on these practices as neglecting them or inability to adopt and ensure its implementation could likely be among the major reasons for poor performance of workforce.

\section{Implications of the Study}

The findings of this research have documented several implications both theoretically and practically. On the theoretical side, this study extends the extant literature on e-HRM practice and job performance by revealing empirical evidence on the link between e-HRM practices and employee task, contextual, adaptive performance, and counterproductive work behaviour.

To the Management and practitioners in the field of job performance, the adoption, implementation and usage of this model will offer them the platform to better understand eHRM practice to pay more attention to in order to optimally improve employee job performance. For instance, the findings revealed that all the practice with exception of e-performance appraisal need to be considered if the goal of organization is higher task performance.

On same note, e-communication and e-compensation are the best practices in promoting all of the four dimensions of job performance (task, contextual, adaptive performance, and counterproductive work behaviour). Summarily, the research opined that Management of tertiary institutions, specifically 
Kaduna Polytechnic should as a matter of urgency embraceHRM practices in order to boost their employees' task, contextual and adaptive performance and minimize the counterproductive work behaviour of their employees.

\section{Limitations and Direction for Future Study}

Even though this research offered additional supports to better understand the influence of e- HRM practices in enhancing and proper management of employee task, contextual, adaptive performance and the counterproductive work behaviour of their staffs. However, the research work had some limitations. Firstly, the study investigated only e-training, e-compensation, e- communication and e-performance appraisal. Therefore, the need for future research that will explore other e-HRM practices like e-recruitment \& selection and other dimensions of job performance, such as organisational citizenship behaviour (OCB) may be fruitful. As e-recruitment \& selection practice will allow the organization to employ the best candidates electronically with required skills and expertise, while the examination of OCB may encourage employees towards behaviours that are positive and constructive with performance. Secondly, in this study the participants located in the Northern Nigeria. Therefore, in order to generalize the findings, future research that will comprise participants from the southern part of Nigeria.

\section{References}

[1] Ho, V. T., Wong, S., \& Lee, C. H. (2011), A Tale of Passion: Linking Job Passion and Cognitive Engagement to Employee Work Performance: A Tale of Passion. Journal of Management Studies 48 (1): 26-47. DOI: 10.1111/j.1467-6486.2009.00878.x.

[2] Stone, D. L., Deadrick, D. L., Lukaszewski, K. M., \& Johnson, R. (2015). The influence of technology on the future of human resource management. Human Resource Management Review, 25 .

[3] Catano, V. M., Wiesner, W. H., Hackett, R. D., \& Methot, L. L. (2009). Recruitment and Selection in Canada. New York: Cengage Learning Inc.

[4] Koopmans, L., Bernaards, C. M., Hildebrandt, V. H., Schaufeli, W. B., De Vet, H. C. W. \& Van der Beek, A. J. (2011), "Conceptual frameworks of individual work performance-a systematic review", Journal of Occupational and Environmental Medicine, 153 (8), 856-66.

[5] Manu, J. S. (2004). Training and Development Techniques for Improving Organizational Performance for Ghanian Firms. United States: University of Wisconsin Stout Menomonie, WI 54751.

[6] Niazi, A. S. (2011). Training and Development Strategy and Its Role in Organizational Performance. Journal of Public Administration and Governance 1, 2.

[7] Decramer, A., Christiaens, J., \& Vanderstraeten, A. (2008). Implementation Dynamics of Performance Management in Higher Education. 21st EIASM Workshop on Strategic Human
Resource Management. Ghent, Belgium: University College Ghent, Voskenslaan 270, 9000.

[8] Pearce, J. L., \& Randel, A. E. (2004). Expectations of organizational mobility, workplace social inclusion, and employee job performance. Journal of Organizational Behavior, 25 (1), 81-98. doi.org/10.1002/job.232।.

[9] Schreurs, B. H. J., Van Emmerik, I. H., Guenter, H., \& Germeys, F. A weekly diary study on the buffering role of social support in the relationship between job insecurity and employee performance. Human Resource Management 51 (2): 259-279. DOI: $10.1002 / \mathrm{hrm} .21465$.

[10] Sony, M., \& Mekoth. (2016). The relationship between emotional intelligence, frontline employee adaptability, job satisfaction and job performance. Journal of Retailing and Consumer Services 30: 20-32. DOI: 10.1016/j.jr.

[11] Han, Y. (2007). The research about influence of organizational commitment on employees work performance, At Zhong nan university of economics and law journal, 03, 56.

[12] Ma, L., Xing, Y., Wang, Y., \& Chen, H. T. (, 2013). Research on the Relationship among Enterprise Employee's Job Satisfaction, Organizational Commitment and Job Performance. Applied Mechanics and Materials, 411 (414), 2477-2480.

[13] Robertson, I. T., Birch, A. J. \& Cooper, C. L. (2012) Job and Work Attitudes, Engagement and Employee Performance: Where Does Psychological Well-Being Fit in? Leadership \& Organization Development Journal, 33, 224-232. doi: $10.1108 / 01437731211216443$.

[14] Dalal, R. S., Baysinger, M., Brummel, B. J., \& LeBreton, J. M. (2012). The relative importance of employee engagement, other job attitudes, and trait affect as predictors of job performance. Journal of Applied Social Psychology, 42 (1), 295-325. doi.org/10.1111/j.1559-1816.2012.01017.x.

[15] Borman, W. C. \& Motowidlo, S. J. (1993), "Expanding the criterion domain to include elements of contextual performance", in Schmitt, N. and Borman, W. C. (Eds), Personnel Selection in Organizations, Jossey Bass, San Francisco, CA, pp. 71-9822] Ebenebe, C. I., Anigbogu, C. C., Anizoba, M. A. and Ufele.

[16] Murphy, K. R. (1989). Dimensions of job performance. Teting: Applied and Theoretic Perspective, 218-247. New York: Praeger.

[17] Tsui, A., Pearce, J., Porter, L., \& Tripoli, A. (1997). Alternative approaches to the employee-organization relationship: does investment in employees pay off? Academy of Management Journal, 40 (5), 1089-1121.

[18] Demortier, A.-L., Delobbe, N., \& El Akremi, A. (2014). Opening the black box of hr practices - performance relationship: Testing a three pathways AMO model. Academy of Management Annual Meeting Proceedings, 1201-1206. doi: 10.5465/AMBPP.2014.102.

[19] Straub, Rai, \& Klein, R. 2004. "Measuring Firm Performance at the Network Level: A Nomology of the Impact of Digital Supply Networks," Journal of Management Information Systems, 21 (1) 83-114.

[20] Wareham, J., Mathiassen, L., Rai, A., Straub, D., \& Klein, R. (2005). "The Business Value of Digital Supply Networks: A Program of Research on the Impacts of Globalization," Journal of International Management, 11 (2), 201-227. 
[21] Bondarouk, T. \& Brewster, C. (2016). Conceptualising the future of HRM and technology research, The International Journal of Human Resource Management, 27 (21), 2652-2671: DOI: $10.1080 / 09585192.2016 .1232296$.

[22] Bondarouk, T. Harms, R. \& Lepak, D. (2015) Does e-HRM lead to better HRM service? The International Journal of Human Resource Management, DOI: 10.1080/09585192.2015.1118139, 4 (3).

[23] Bondarouk, T., Parry, E, \& Furtmueller, E. (2017). Electronic HRM: four decades of research on adoption and consequences, The International Journal of Human Resource Management, $1-34$.

[24] Ulrich, D. \& Dulebohn, J (2015). Are we there yet? What's next for HR? Journal of Human Resource Management Review. 25 (2), 178-186.

[25] Stone, D. L., \& Dulebohn, J. H. (2013). Emerging issues in theory and research on electronic human resource management (e-HRM). Human Resource Management Review, 23 (1), 1-5.

[26] Masum, A. K. M (2015) Adoption Factors of Electronic Human Resource Management (e-HRM) in Banking Industry of Bangladesh. Journal of Social Sciences, 11 (1), 1-6.

[27] Yusoff, Y. M., Ramayah, T., \& Othman, N. (2015). "Why Examining Adoption Factors, HR Role and Attitude towards Using E-HRM is the Start-Off in Determining the Successfulness of Green HRM?," Journal of Advanced Management Science, 3 (4), 337-343.

[28] Dialoke I. \& Goddey C. (2017). Electronic human resource management and ghost workers syndrome in Nigeria: A study of selected LGAs in IMO state, Advance Research Journal of Multidisciplinary Discoveries, 10 (2017): 52-57.

[29] Obasanjo, O. (2003). Presidential speech at the inauguration ceremony of the new members of the national assembly, on 5th june, 2003. Abuja, Nigeria.

[30] Suleiman, W. (2013). A Study of Causes of Poor Attitude to Work among workers of both Public and Private Sectors Organizations in Bauchi State-Nigeria. International Journal of Academic Research in Business and Social Sciences, 3 (7), 143-152.

[31] Koopmans, L., Bernaards, C. M., Hildebrandt, V. H., Schaufeli, W. B., De Vet, H. C. W. \& Van der Beek, A. J., (2012)"Development of an individual work performance questionnaire", International Journal of Productivity and Performance Management, 62 (1), 6-28.

[32] Inyang, B. J., \& Akaegbu, J. B. (2014). Redefining the Role of the Human Resource Professional (HRP) in the Nigerian Public Service for Enhanced Performance. International Journal of Business Administration, 5 (1), 90-98.

[33] Duarte, P. A. O., \& Raposo, M. L. B. (2010). A PLS model to study brand preference: An application to the mobile phone market. In V. Esposito Vinzi, W. W. Chin, J. Henseler \& H. Wang (Eds). In Handbook of Partial Least Squares: Concepts, methods and applications (pp. 449485).). Berlin: Springer.

[34] Rotundo, M. \& Sackett, P. R. (2002), "The relative importance of task, citizenship, and counterproductive performance to global ratings of performance: a policy-capturing approach", Journal of Applied Psychology, 87 (1), 66-80.
[35] Jex (1998), Stress and Job Performance: Theory, Research, and Implications for Managerial Practice, Sage Publications, Thousand Oaks, CA.

[36] Chen, C. F. (2014), “The influences of university interns' job characteristics, work value, and job performance", Revista de Cercetare si Interventie Sociala, 47 (1), 204-219.

[37] Motowidlo, S. J. (2003). Job performance. In I. B. Weiner (Ed.), Handbook of psychology (Vol. 12). New Jersey: John Wiley \& Sons Inc., Hoboken.

[38] Hunt S. T. (1996). Generic work behavior: an investigation into the dimensions of entry-level, hourly job performance. Personnel Psychology. 49: 51-83.

[39] Viswesvaran, C. \& Ones, D. S. (2000), "Perspectives on models of job performance", International Journal of Selection and Assessment, 8 (4), 216-26.

[40] Werner, J. M. (2000), "Implications of OCB and contextual performance for human resource management", Human Resource Management Review, 10 (1), 3-24.

[41] Maxham J. G. I, Netemeyer, R. G, \& Lichtenstein, D. R. (2008) The retail value chain: linking employee perceptions to employee performance, customer evaluations, and store performance. Market Sci. 27, 147-167.

[42] Frese, M., Garst, H., \& Fay, D. (2007). Making things happen: Reciprocal relationships between work characteristics and personal initiative in a four-wave longitudinal structural equation model. Journal of Applied Psychology, 92, 1084-1102.

[43] Sonnentag, S., \& Frese, M. (2002). Performance concepts and performance theory. Psychological management of individual performance, 23, 3-25.

[44] Bertua, C., Anderson, N., \& Salgado, J. F. (2005). The predictive validity of cognitive ability tests: A UK meta-analysis. Journal of Occupational and Organizational Psychology, 78 (3), 387409. doi.org/10.1348/096317905X26994.

[45] Bhatt, T. (2015), E-HRM review and implications, Journal of Advances in Business Management, 1 (4), 387-389. DOI; $10.14260 / \mathrm{jadbm} / 2015 / 49$.

[46] Strohmeier, S. (2007). 'Research in e-HRM: Review and implications'. Human Resource Management Review, 17: 19-37.

[47] Marler, J. H., \& Fisher, S. L. (2013). An evidence-based review of e-HRM and strategic human resource management. Human Resource Management Review, 23 (1), 18-36.

[48] Withers, M. Williamson, M. and Reddington, M (2010) Transforming HR Creating Value Through People. 2nd edition. London. Elsevier.

[49] Pradhan, S. K. \& Chaudhury, S. K. (2012). A survey on Employee Performance Management and its Implication to their Retention in OCL India Ltd. Asian Journal of Research in Social Science \& Humanities, 2 (4), 249-262.

[50] Van Scotter, J. R., Motowidlo, S. J. \& Cross, T. C. (2000), "Effects of task and contextual performance on systematic rewards", Journal of Applied Psychology, 85 (4), 526-535.

[51] Wilson, J 2005, Human resource development: learning \& training for individuals and organizations, 2nd edn, Kogan Page. 
[52] Cunningham, I. (2007). Talent management: Making it real. Development and Learning in Organisations, 21 (2), 4-6.

[53] Pratheepan S, Arulrajah A. (2012). Application of Electronic Human Resource Management (E-HRM) Practices and its Effectiveness in Selected Private Banks in Sri Lanka: An Exploration, the Seventh International Research Conference on Management and Finance, 159- 175.

[54] Mohsin, M., \& Sulaiman, R. (2013). A Study on E-Training Adoption for Higher Learning Institutions. International Journal of Asian Social Science. 3 (9), 2006-2018.

[55] Hardman, W. \& Robertson, L. (2012). What motivates employees to persist with online training? International Journal of Business Humanities and Technology, 2 (5), 66-78.

[56] Nenwani, P., \& Raj, M. (2009). E-HRM Prospective in Present Scenario. International Journal, 1 (7), 2013.

[57] Welsh, E. T., Wanberg, C. R., Brown, K. G., \& Simmering, M J. (2003). E-learning: Emerging uses, empirical results and future directions. International Journal of Training and Development, 7, 245-258.

[58] Ensher, E. A., Nielson, T. R., \& Grant-Vallone, E. (2002). Tales from the hiring. line: effects of the internet and technology on HR processes. Org. Dyn. 31 (3), 224-244.

[59] Kamal, K. B., Aghbari, M. A., \& Atteia, M. (2016). E-training $\&$ employees' performance a practical study on the ministry of education in the kingdom of Bahrain. Journal of Resources Development and Management. 18.

[60] Hilb, M. (1992). Management development in Western Europe in the 1990's' Journal of Human Resource Management, 3 (3): 575-84.

[61] Sambrook, S. (2003). E-learning in small organizations. Education and Training, 45 (8/9), 506.

[62] Gratton-Lavoie \& Stanley, (2009) Teaching and Learning Principles of Microeconomics Online: An Empirical Assessment. Journal of Economic Education, 40 (1), 3-25.

[63] Lorenzetti, J. (2013.). Academic Administration - Running a MOOC: Secrets of the World's Largest Distance Education Classes - Magna Publications.

[64] Ellis, F \& Kuznia, K. (2014). Coporate E-Learning Impact on Employees. Global Journal of Business Research, 8 (4), 1-5.

[65] Chen, E. T. (2008) "Successful E-learning in corporations". Communications of the IIMA, 8 (2), 45-II.

[66] Newton, R., \& Doonga, N. (2007). "Corporate e-learning: Justification for implementation and evaluation of benefits. A study examining the views of training managers and training providers". Education For Information, 25 (2), 111-130.

[67] Nguyen, T, (2015). The Effectiveness of Online Learning: Beyond No Significant Difference and Future Horizons, MERLOT Journal of Online Learning and Teaching, 11 (2), 309-319.

[68] Leković, B., \& Berber, N. (2014). The Relationship Between Communication Practice and Organizational Performances in Organizations from Europe. Industrija, 42 (3), 101.

[69] Panayotopoulou, L., Vakola, M., \& Galanaki, E. (2007). E HR adoption and the role of HRM: Evidence from Greece. Personnel Review, 36, 277-294.
[70] Fındıklı M. A. \&, Bayarçelikb, E. B. (2015). Exploring the outcomes of Electronic Human Resource Management (E-HRM)? Social and Behavioral Sciences 207 (2015) 424-431.

[71] Mano R. S \& Mesch G. S. (2010). E-mail characteristics, work performance and distress. Computers in Human Behavior 26 (2010) 61-69.

[72] Gartner. (2008). “Gartner Says Emerging Nations Will Make ICT Industry 'Borderless' by 2015," Gartner Group, May 14 (http://www.gartner.com/it/page.jsp?id=669710; accessed November 24, 2008).

[73] Hill, N. S., Kang, J. H., \& Seo, M.-G. (2014). The interactive effect of leader-member exchange and electronic communication on employee psychological empowerment and work outcomes. The Leadership Quarterly, 25 (4), 772-783.

[74] Zhang, X. \& Venkatesh, V. (2014), Explaining Employee Job Performance: The Role of Online and Offline Workplace Communication Networks, MIS Quarterly 37 (3): 695-722.

[75] Kariznoee, A., Afshani, M., \& Moghadam, M. R. H. (2012). To examine the effect of E-HRM on employee's job performance. Advanced Research in Economic and Management Sciences (AREMS), 6, 275-282.

[76] Dulebohn, J. H., \& Marler, J. H. (2005). E-Compensation: The potential to transform practice. In H. G. Gueutal, \& D. L. Stone (Eds.), The brave new world of e HR: Human resources management in the digital age (pp. 166-189). San Francisco: Jossey Bass.

[77] Ukandu N. E., Iwu C. G., \& Allen-lle C. O. K. (2014). Influence of E-HRM in decision making in selected tertiary institutions in South Africa. Problems and Perspectives in Management, 12 (4), 397-405.

[78] Akter N., \& Husain, M. M., (2016). Effect of Compensation on Job Performance: An Empirical Study. International Journal of Engineering Technology, Management and Applied Sciences, 4 (8), 103-116.

[79] Onuorah, A. N., Okeke, M. N., \& Ikechukwu, I. A. (2019). Compensation Management and Employee Performance in Nigeria. International Journal of Academic Research in Business and Socal Sciences, 9 (2), 384-398.

[80] Adewale O. O., Adenike A. A., Hezekiah O. F., \& Heirsmac T. (2014). Compensation packages: a strategic tool for employees' performance and retention. Leonardo Journal of Sciences, 25, 65-84.

[81] Piggot-Irvine E., (2003). Appraisal Training Focused on What Really Matters. International Journal of Educational Management, $17 \quad$ (6), 254-261. DOI: $10.1108 / 09513540310487587$.

[82] Johnson, R. D.\& Gueutal, H. G.(2011). Transforming HR through technology: the use of hER and human resource information systems in organizations. Alexandria, VA: SHRM Effective Practice Guidelines Series.

[83] Summer, L. (2001). Web technologies for administering multisource feedback programs: In D Bracken, C. W. Timmreck \& A. H Church (Eds). The handbook of multisource feedback (pp. 6165-180) San Francisco: Jossey-Bass.

[84] Kavanagh, M. J., Thite, M.\& Johnson, R. D. (Eds.). (2015). Human resource information systems: basics, applications and future directions. 3rd Edition. Thousand Oaks, CA: Sage. 
[85] Morgenson, F. P., Mumford, T. V., \& Campion, M. A. (2005). Coming full circle: Using research and practice to address 27 questions about 360-degree feedback programs. Consulting Psychology Journal, 57, 196-209.

[86] Jarrar, Y., \& Schiuma, G. (2007). Measuring performance in the public sector: challenges and trends. Measuring Business Excellence, 11 (4), 4-8.

[87] Al-Raisi, A., Amin, S., \& Tahir, S. (2011), Evaluation of e-performance analysis and assessment in the United Arab Emirates (UAE) Organizations, Journal of Internet \& Information System, 2 (2), 20-27.

[88] Neary, D. B. (2002), "Creating a company-wide, on-line, performance management system: a case study at TRW Inc", Human Resource Management, 41 (4), 491-8.

[89] Gueutal, H. G.\& Falbe, C. M. (2005). E-HR: trends in delivery methods. In H. G. Gueutaland D. L. Stone (Eds.). The brave new world of e-HR: human resource management in the digital age (pp. 190-225). San Francisco, CA: Jossey-Bass.

[90] Stanton, J. M. (2000). Reactions to Employee Performance Monitoring: Framework, Review, and Research Directions. Human Performance, 13 (1): 85-113.

[91] Moorman, R. H., \& Wells, D. L. (2003). Can electronic performance monitoring be fair? Exploring relationships among monitoring characteristics, perceived fairness, and job performance. Journal of Leadership and Organizational Studies, 10 (2), 2-16.

[92] Payne, S. C., Horner, M. T., Boswell, W. R., Schroeder, A. N. \& Stine-Cheyne, K. J. (2009). Comparison of online and traditional performance appraisal systems. Journal of Managerial Psychology, 24 (6), 526-544.

[93] Petrakaki, D., Klecun, E., \& Cornford, T. (2014). Changes in healthcare professional work afforded by technology: The introduction of a national electronic patient record in an English hospital.

[94] Qureshi, T. M., Akbar, A., \& Khan, M. (2010). Do human resource management practices have an impact on financial performance of banks? African Journal of Business and Management, 4 (7), 1281-1288.

[95] Hair, J. F., Jr., Black, W. C., Babin, B. J., Andersen, R. E., \& Tatham, R. L. (2010). Mutilvariate data analysis (7th ed). Upper Saddle River, NJ: Pearson Prentice Hall.

[96] Tabachnick, B. G. \& Fidell, L. S. (2007). Using multivariate statistics (5th ed). Boston: Pearson Education Inc.
[97] Wold, H. (1974). Causal flows with latent variables: Partings of the ways in the light of NIPALS modelling. European Economic Review, 5, 67-86. doi: 10.1016/0014-2921.

[98] Chin, W. W., \& Newsted, P. R. (1999). Structural equation modeling analysis with small samples using partial least squares. In R. Hoyle (Ed.). In Statistical strategies for small sample research (pp. 307-341).). Thousand Oaks, CA: Sage Publication.

[99] Reinartz, W. J., Haenlein, M., \&, \& Henseler, J. (2009). An Empirical Comparison of the Efficacy of Covariance-Based and Variance-Based SEM. International Journal of Research in Marketing, 26 (4), 332-344.

[100] Hair, J. F., Sarstedt, M., Hopkins, L., \& Kuppelwieser, V. G. (2014). Partial least squares structural equation modeling (PLS-SEM). European Business Review, 26, 106-121. doi: doi: 10.1108/EBR-10-2013-0128.

[101] Henseler, J., Ringle, C. M., \& Sinkovics, R. R. (2009). The use of partial least squares path modeling in international marketing. In R. R. Sinkovics \& P. N. Ghauri (Eds.), Advances in International Marketing (Vol. 20, pp. 277-320). Bingley: Emerald.

[102] Hair, J. F., Sarstedt, M., Ringle, C. M., \& Mena, J. A. (2012). An assessment of the use of partial least squares structural equation modeling in marketing research. Journal of the Academy of Marketing Science, 40, 414-433. doi: 10.1007/s11747-011-0261.

[103] Hair, J. F., Hult, G. T. M., Ringle, C. M., \& Sarstedt, M. (2013). A Primer on Partial Least Squares Structural Equation Modeling (PLS-SEM). Thousand Oaks: SAGE.

[104] Hulland, J. (1999). Use of partial least squares (PLS) in strategic management research: a review of four recent studies. Strategic Management Journal, 20 (2), 195-204.

[105] Bagozzi, R. P., \& Yi, Y. (1988). On the evaluation of structural equation models. Journal of the Academy of Marketing Science, $16(1), 74-94$.

[106] Fornell, C., \& Larcker, D. F. (1981). Evaluating structural equation models with unobservable variables and measurement models. Journal of Marketing Research, 39-50.

[107] Chin, W. W. (1998). The partial least squares approach to structural equation modeling. In G. A. Marcoulides (Ed.), Modern Methods for Business Research (pp. 295-336). Mahwah, New Jersey: Laurence Erlbaum Associates. 